Article

\title{
Synthesis of Quinolin-2-one Alkaloid Derivatives and Their Inhibitory Activities against HIV-1 Reverse Transcriptase
}

\section{Pi Cheng ${ }^{1,3, *}$, Qiong Gu ${ }^{2}$, Wei Liu ${ }^{1}$, Jian-Feng Zou ${ }^{1}$, Yang-Yong Ou ${ }^{3}$, Zhong-Yong Luo ${ }^{3}$ and Jian-Guo Zeng ${ }^{1,3, *}$}

1 National Research Center of Engineering Technology For Utilization of Functional Ingredients From Botanicals, College of Horticulture and Landscape Architecture, Hunan Agricultural University, Changsha 410128, Hunan, China; E-Mails: 1whncs618@163.com (W.L.); zoujf2005@163.com (J.-F.Z.)

2 School of Pharmaceutical Sciences, Sun Yat-Sen University, Guangzhou 510006, Guangdong, China; E-Mail: guqiong@sysu.edu.cn (Q.G.)

3 Hunan Engineering Research Center of Botanical Extract, Changsha410128, Hunan, China; E-Mails: oyy713@163.com (Y.-Y.O.); zhongyongluo@hotmail.com (Z.-Y.L.)

* Authors to whom correspondence should be addressed; E-Mails: picheng55@126.com (P.C.); ginkgo@world-way.net (J.-G.Z.); Tel.: +86-731-8468-6560; Fax: +86-731-8468-6560.

Received: 16 June 2011; in revised form: 4 August 2011 / Accepted: 20 August 2011 /

Published: 7 September 2011

\begin{abstract}
Based on an established common pharmacophore of HIV-1 non-nucleoside reverse transcriptase inhibitors (NNTTIs), a series of quinolin-2-one derivatives were synthesized and assayed for their in vitro activities against HIV-1 reverse transcriptase (RT) for the first time. Some of the tested compounds were active against HIV-1 RT. Compounds $4 \mathbf{a} 2$ and $\mathbf{4 d 2}$ showed inhibitory activities with $\mathrm{IC}_{50}$ values of 0.21 and 0.15 $\mu \mathrm{M}$, respectively, with a mode of interaction with RT residues of the allosteric pocket similar to that of efavirenz.
\end{abstract}

Keywords: quinolin-2-one; alkaloid; synthesis; HIV-1 RT; activity 


\section{Introduction}

AIDS (Aquired Immune Deficiency Syndrome), caused by human immunodeficiency virus (HIV), a RNA dependent retrovirus, remains one of the major causes of death in the World. HIV-1 reverse transcriptase (RT) is one of the enzymes crucial for the HIV virus replication cycle. Upon entering a host cell, the single stranded viral RNA is converted to double-stranded DNA catalyzed by RT and then the virus DNA inserts into the genome of the host cell. Inhibition of reverse transcriptase (RT), the HIV-encoded polymerase which directs both RNA and DNA synthesis, has been proven to be one of the most effective ways to block viral multiplication [1-5].

Based on the ready availability of X-ray crystal structures of inhibitor-HIV RT complexes, Freeman and colleagues have identified the common pharmacophore $N$-(4-chlorophenyl)acetamide (1) from an array of known non-nucleoside reverse transcriptase inhibitors [6] such as efavirenz, DPC961, HBY097 and the newly reported benzoimidazol-2-one [7] and dihydroquinoxalin-2-one [8] NNTRIs (Figure 1).

Figure 1. NNRTI pharmacophore $N$-(4-chlorophenyl)acetamide (1) and related anti-HIV-1 RT active compounds.

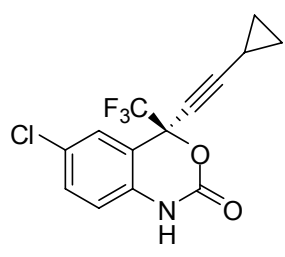

Efavirenz

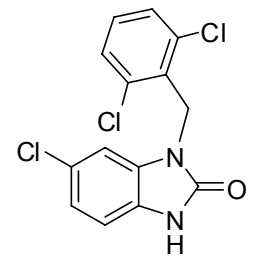

benzoimidazol-2-one

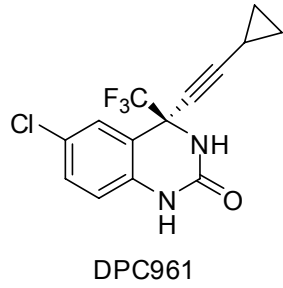

DPC961

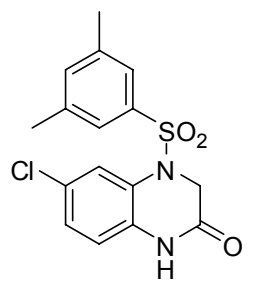

dihydroquinoxalin-2-one

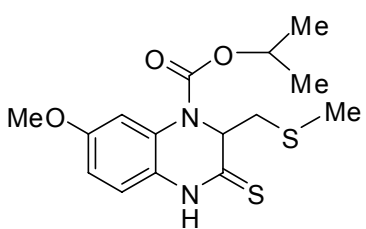

HBY097

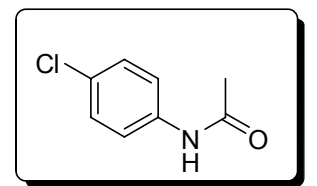

$\mathrm{N}$-(4-chlorophenyl)acetamide 1

A series of substituted 2-quinolones (2, Figure 2) were synthesized and evaluated as HIV-1 inhibitors in Freeman's research. As to natural products, a similar quinolin-2-one alkaloid $\mathbf{3}$ isolated from Euodia roxburghiana reported by McCormick also showed inhibitory activity with an $\mathrm{IC}_{50}$ of 8 $\mu \mathrm{M}$ in an HIV-1 reverse transcriptase (RT) assay [9].

Figure 2. quinolin-2-one NNRTIs and newly designed derivatives.

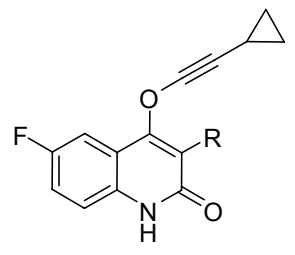

2<smiles>CC(C)=CCOc1c(CC=C(C)C)c(=O)[nH]c2ccccc12</smiles>

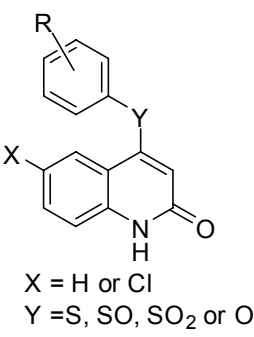

4<smiles>O=c1cc(-c2ccccc2)c2cc(Cl)ccc2[nH]1</smiles>

5 
Based on the pharmacophore established by Freeman, we designed and synthesized a series of 4-substituted quinolin-2-one alkaloids $\mathbf{4}$ and 5, as shown in Figure 2. We envisaged that replacement of the cyclopropylethynyloxy moiety with a hydrophobic aromatic ring would retain the inhibitory activity against HIV-1 RT [4,10-13]. In compounds 4, the group Y could be oxygen, sulfur, sulfinyl or sulfonyl units, which were flexible linkers to connect the hydrophobic phenyl group with the quinolin2-one scaffold. To identify the importance of the linker, compounds $\mathbf{5}$ were synthesized with an aromatic ring directly connected to quinoline-2-one scaffold. In this paper, we report the synthesis of compounds $\mathbf{4}$ and $\mathbf{5}$ and the evaluation of the synthesized compounds for their in vitro inhibitory activities against HIV-1 RT for the first time.

\section{Results and Discussion}

\subsection{Chemistry}

The syntheses of compounds 4 is summarized in Schemes 1 and 2, respectively. 3-Hydroxyquinolin-2-one (8, Scheme 1) has been the subject of intensive synthetic studies for a long time. Among the synthetic strategies used is the Friedel-Crafts reaction [6]. Freeman reported that a treatment with aniline or 4-chloroaniline $\mathbf{6}$ and excess of diethyl malonate in diphenyl ether at $250{ }^{\circ} \mathrm{C}$ for $24 \mathrm{~h}$ afforded cyclized compound $\mathbf{8}$ directly. But in our study, target compound $\mathbf{8}$ was not obtained under these conditions and only some amide intermediates could be detected by HPLC-ESIMS. We thus irradiated a mixture of aniline and diethylmalonate (2:1 molar ratio) under microwaves and prepared corresponding dimalonamide 7 in good yield. Heating $N, N^{\prime}$-di(4-chlorophenyl)malonamide in polyphosphoric acid (PPA) at $140-150{ }^{\circ} \mathrm{C}$ afforded the 4-hydroxy-2-quinolone 8 (Scheme 1) [14]. Refluxing compound 8 in $\mathrm{POCl}_{3}$ provided 2,4,6-trichloroquinoline 9 in good yield. A phenylthio group was then installed on the quinoline ring to afforded compounds 10, which were converted to target compounds 4a through a microwave assisted hydrolysis in mixture of TFA and $\mathrm{HCl}$ [15]. Compounds 4a were oxidized to target compounds $\mathbf{4 b}$ as racemates, and these were then converted to compounds $\mathbf{4 c}$ by reaction with another 1.1 equiv. of 3 -chlorobenzoperoxoic acid ( $m$-CPBA).

Scheme 1. Synthesis of target compounds $\mathbf{4 a - 4 c}$.

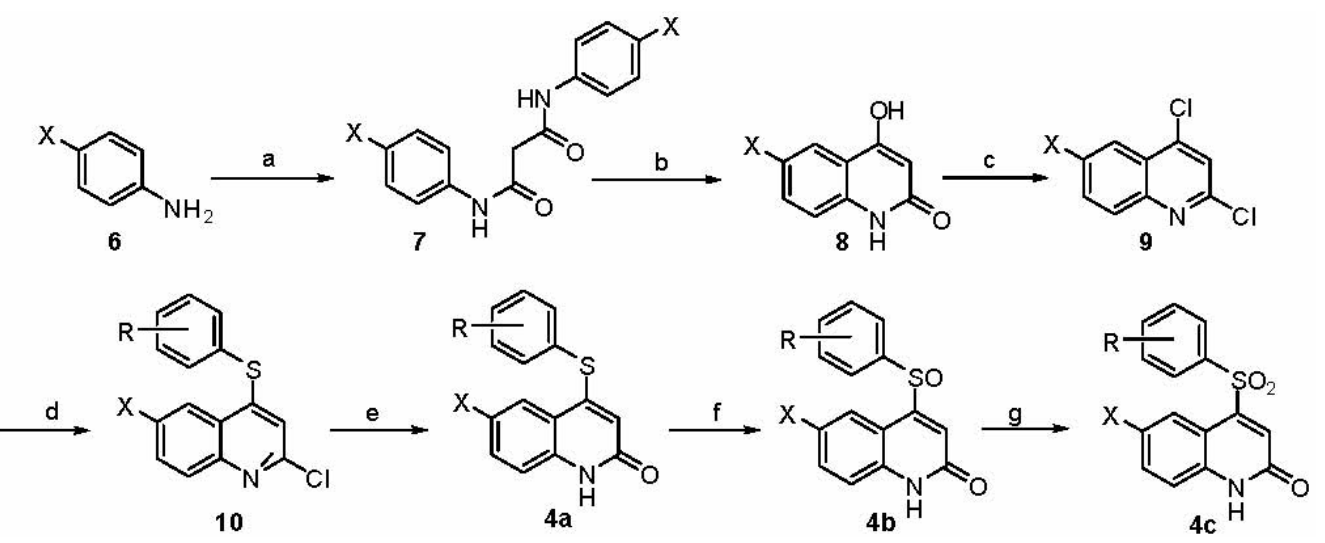

Reagents and conditions: (a) diethylmalonate, MW (320 W), $10 \mathrm{~min}$; (b) PPA, 140-150 ${ }^{\circ} \mathrm{C}, 6 \mathrm{~h}$; (c) $\mathrm{POCl}_{3}$, reflux, $3 \mathrm{~h}$; (d) benzenethiol, 1.0 eq, Et ${ }_{3} \mathrm{~N}, \mathrm{DMF}, 0{ }^{\circ} \mathrm{C} \rightarrow \mathrm{rt}$, overnight; (e) TFA, HCl, MW (320 W), 20 min; (f) $m$-CPBA, 1.1 equiv., $\mathrm{CH}_{2} \mathrm{Cl}_{2}$, $\mathrm{MeOH}$, rt; (g) $m$-CPBA, 1.1 equiv., $\mathrm{CH}_{2} \mathrm{Cl}_{2}$, $\mathrm{MeOH}, \mathrm{rt}$. 
The synthesis of compounds $4 \mathbf{d}$ shared the same synthetic precursor 2,4,6-trichloroquinoline 9 (Scheme 2). Through treatment of compound 9a with various phenols followed by hydrolysis in acid mixtures, compounds $\mathbf{4 d}$ were synthesized in moderate yields using the conditions described above without need for further optimization.

Scheme 2. Synthesis of target compounds $\mathbf{4 d}$.

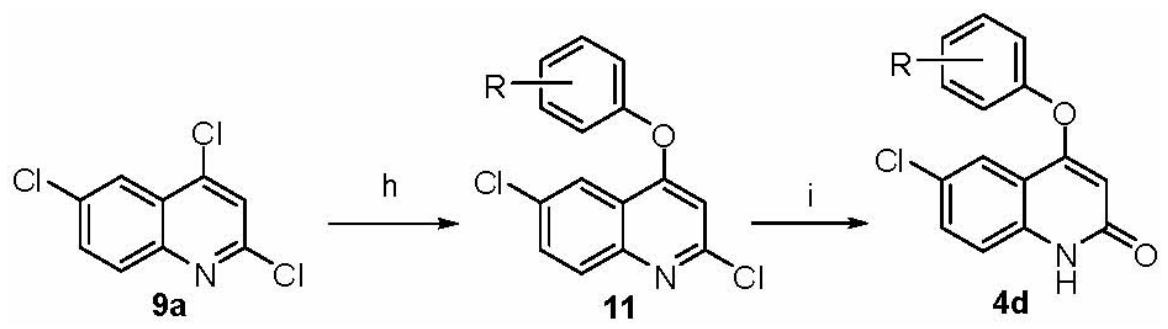

Reagents and conditions: (h) phenol, 1.0 eq. $\mathrm{Et}_{3} \mathrm{~N}, \mathrm{DMF}, 0{ }^{\circ} \mathrm{C} \rightarrow \mathrm{rt}$, overnight; (i) $\mathrm{TFA}, \mathrm{HCl}, \mathrm{MW}$ $(320 \mathrm{~W}), 20 \mathrm{~min}$.

The synthetic route of target compounds 5 was summarized in Scheme 3. The synthesis of $\mathbf{5}$ by various methods has been reviewed. The majority of compounds $\mathbf{1 3}$ were prepared by the reaction of aryl esters with ortho-lithiated Boc-protected 4-chloroaniline via the formation of the dianion species with $t$-BuLi (2.2 equiv) followed by deprotection of the Boc group (Scheme 3) [16,17]. A tandem amidation/Knoevengel condensation of compounds $\mathbf{1 3}$ with ethyl acetate gave compounds $\mathbf{5}$ in good yields.

Scheme 3. Synthesis of target compounds 5.

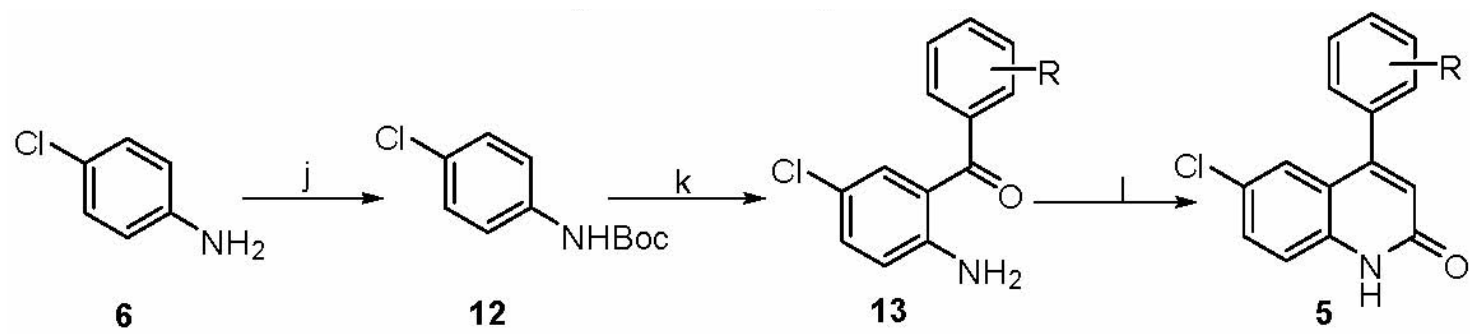

Reagents and conditions: (j) (Boc) $)_{2} \mathrm{O}$, DIEA, DCM; $(\mathrm{k})-78^{\circ} \mathrm{C}, t$-BuLi, then add $\mathrm{R}^{1}-\mathrm{PhCOOMe}$ at $-40{ }^{\circ} \mathrm{C}$ and warmed up to $0{ }^{\circ} \mathrm{C}$, then $3 \mathrm{~N} \mathrm{HCl}, \mathrm{EtOH}$, reflux, in three steps; (1) $0{ }^{\circ} \mathrm{C}$, LiHMDS, EtOAc.

\subsection{Enzymatic Activities}

Compounds $4 \mathbf{a}-\mathbf{4 d}$ were tested in RT inhibition assays and proved to be active as inhibitors of HIV-1 RT (Table 1). The enzymatic data highlighted that derivative $\mathbf{4 a 2}\left(\mathrm{IC}_{50}=0.21 \mu \mathrm{M}\right)$ and $\mathbf{4 d} \mathbf{2}$ $\left(\mathrm{IC}_{50}=0.15 \mu \mathrm{M}\right)$ turned out to be more active than $4 \mathbf{a 3}\left(\mathrm{IC}_{50}=13 \mu \mathrm{M}\right)$, respectively, and suggested that the presence of a chlorine substituent at C-6 may lead to an increase of potency and influence the affinity to the enzyme. This finding is in agreement with the $N$-(4-chlorophenyl)acetamide pharmacophore established by Freeman, and new type of anti-HIV-1 RT compounds could be designed based on the pharmacophore model. 
Table 1. HIV-1 RT inhibitory activities of compounds $4-5 .{ }^{\text {a }}$

\begin{tabular}{ccccc}
\hline Compounds & $\mathbf{X}$ & $\mathbf{Y}$ & $\mathbf{R}$ & $\mathbf{I C}_{\mathbf{5 0}}\left(\boldsymbol{\mu M} \mathbf{M}^{\mathbf{b}, \mathbf{c}}\right.$ \\
\hline $\mathbf{4 a 1}$ & $\mathrm{Cl}$ & $\mathrm{S}$ & $\mathrm{H}$ & 5.6 \\
$\mathbf{4 a 2}$ & $\mathrm{Cl}$ & $\mathrm{S}$ & $3,5-\mathrm{CH}_{3}$ & 0.21 \\
$\mathbf{4 a 3}$ & $\mathrm{H}$ & $\mathrm{S}$ & $3,5-\mathrm{CH}_{3}$ & 18 \\
$\mathbf{4 b 1}$ & $\mathrm{Cl}$ & $\mathrm{SO}$ & $\mathrm{H}$ & 8.9 \\
$\mathbf{4 b 2}$ & $\mathrm{Cl}$ & $\mathrm{SO}$ & $3,5-\mathrm{CH}_{3}$ & 2.6 \\
$\mathbf{4 c 1}$ & $\mathrm{Cl}$ & $\mathrm{SO}_{2}$ & $\mathrm{H}$ & 49 \\
$\mathbf{4 c 2}$ & $\mathrm{Cl}$ & $\mathrm{SO}_{2}$ & $3,5-\mathrm{CH}_{3}$ & 10 \\
$\mathbf{4 d 1}$ & $\mathrm{Cl}$ & $\mathrm{O}$ & $\mathrm{H}$ & 3.0 \\
$\mathbf{4 d 2}$ & $\mathrm{Cl}$ & $\mathrm{O}$ & $3,5-\mathrm{CH}_{3}$ & 0.15 \\
$\mathbf{5 a}$ & $\mathrm{Cl}$ & $/$ & $\mathrm{H}$ & $>100$ \\
$\mathbf{5 b}$ & $\mathrm{Cl}$ & $/$ & $2-\mathrm{F}$ & $>100$ \\
$\mathbf{5 c}$ & $\mathrm{Cl}$ & $/$ & $2-\mathrm{Cl}$ & $>100$ \\
\hline
\end{tabular}

${ }^{\mathrm{a}}$ All values are the mean of two independent experiments; ${ }^{\mathrm{b}}$ The inhibition of recombinant HIV-1 RT activity was performed with a commercially available ELISA kit (Roche) according to the instructions of the manufacturer. $\mathrm{IC}_{50}=$ effective concentration that inhibits $50 \%$ of HIV-1 RT; ${ }^{c}$ Efavirenz: an HIV-1 RT inhibitor used as positive control. $\mathrm{IC}_{50}=6 \mathrm{nM}$.

In addition, the type of linker which connected the aromatic ring with the quinoline scaffold might be crucial for potent anti-HIV-1 RT activity in the title compounds. Comparing compounds $4 \mathbf{2} 2$ $\left(\mathrm{IC}_{50}=0.21 \mu \mathrm{M}\right), \mathbf{4 b 2}\left(\mathrm{IC}_{50}=2.6 \mu \mathrm{M}\right)$ and $\mathbf{4 c 2}\left(\mathrm{IC}_{50}=10 \mu \mathrm{M}\right)$, a decrease of activity against $\mathrm{RT}$ could be observed as the degree of oxidation of the sulfur atom increased. The role of the substituents of the phenyl ring on the biological activities was also investigated, as shown in Table 1. In compounds $4 \mathbf{a 1}$ $\left(\mathrm{IC}_{50}=5.6 \mu \mathrm{M}\right)$ and $4 \mathbf{a} 2\left(\mathrm{IC}_{50}=0.21 \mu \mathrm{M}\right)$, two hydrophobic methyl group on the phenyl ring led to potent enzyme activity, and may contribute to the ability to bind with the hydrophobic site of RT. In contrast, compounds 5a-5c exhibited obviously decreased activities towards the enzyme. We envisagd that hydrophobic interaction ability was influenced by the rigid conjugation system between the phenyl ring and the quinolin-2-one scaffold.

\subsection{Docking Studies}

To investigate the binding mode of the synthesized quinolin-2-ones, computational modeling was performed using CDOCK. The CHARMM force field was used for the energy minimizations in the docking process. The coordinates of the RT-wfavirenz complex (PDB code: 1FK9) [12,18] were downloaded, and the molecular structure of the most potent compounds $\mathbf{4 a 2}$ and $\mathbf{4 d \mathbf { 2 }}$ were docked into its active site. The best docked conformation of compounds $\mathbf{4 a 2}$ and $\mathbf{4 d} \mathbf{2}$ were shown in Figure 3, together with the experimental position of efavirenz and the 3D common-feature pharmacophore model. Compounds $\mathbf{4 a 2}$ and $\mathbf{4 d 2}$ interact with RT residues of the allosteric pocket in a fashion similar to known NNRTIs. The $p$-chloroaniline moiety has a hydrophobic contact with the surrounding residues such as Tyr318, Pro236, Leu234 and Val106. The carboxamide group of the molecule interacts with the main-chain of Lys101 by hydrogen bond interactions. The 3,5-dimethylphenyl fragment occupies a hydrophobic pocket consisting of Pro95, Tyr181, Tyr188 and Trp229, which is 
occupied by the cyclopropyl-propynyl of efavirenz in the complex. One of the two methyl groups on the benzene ring adopts a similar orientation to the cyclopropyl group of efavirenz.

Figure 3. CDOCK-modeled binding mode of $\mathbf{4 a 2}$ (left) and $\mathbf{4 d 2}$ (right) in comparison with the crystal structure (1FK9 in PDB) of efavirenz (orange colored carbon atoms). The key hydrogen bond is illustrated with green lines.
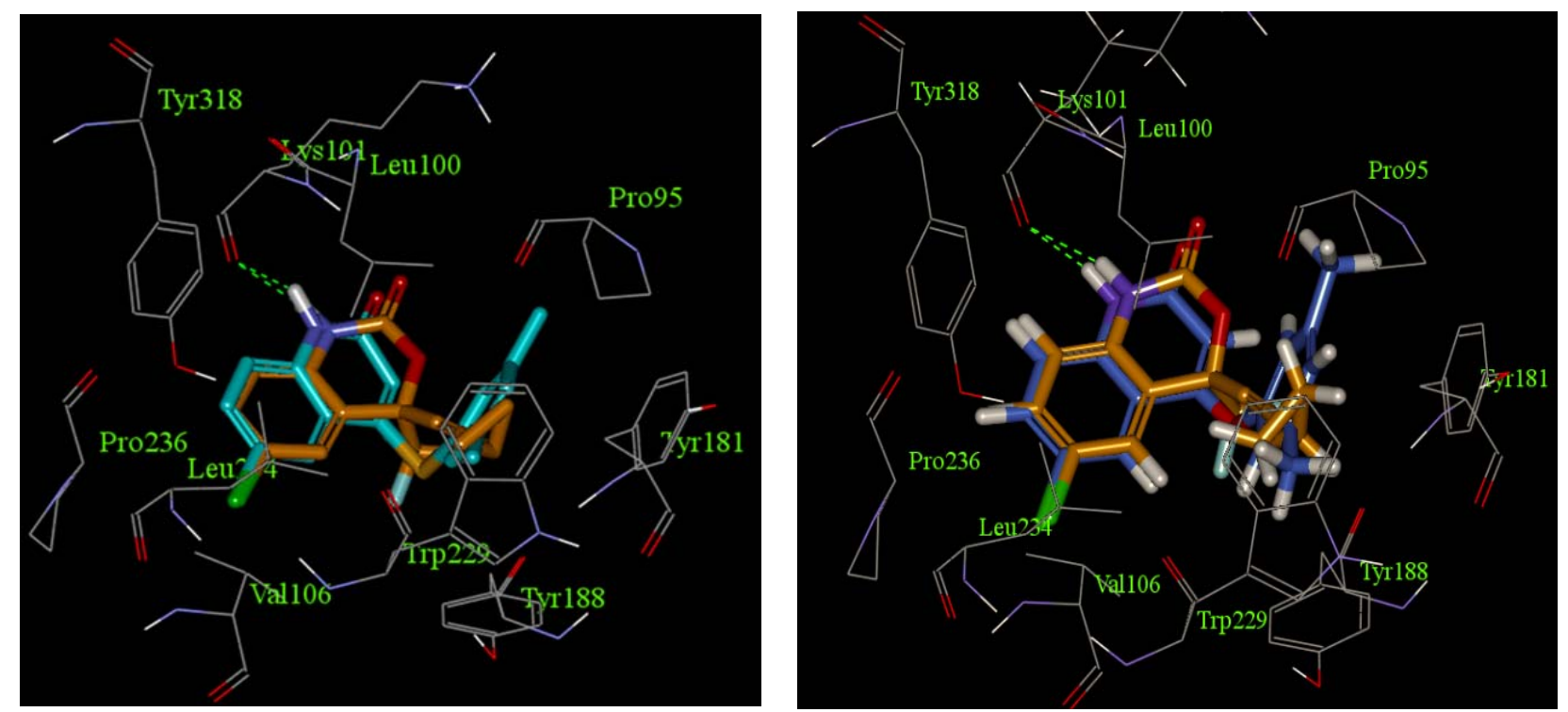

\section{Experimental}

\subsection{Chemistry}

\subsubsection{Instruments and Materials}

Column chromatography silica gel (200-300 mesh) and TLC plate (Qingdao Meijin Chemical Inc.; Qingdao; China); MS data were obtained on an AutoSpec-3000 or Agilent HPLC-ESIMS; ${ }^{1} \mathrm{H}-\mathrm{NMR}$ spectra were recorded on Bruker 300M or DRX-500 spectrometers and chemical shifts were given in $\delta$ with TMS as an internal reference. All the reagents are commercial available. Tetrahydrofuran (THF) was refluxed over Na before use.

\subsubsection{General Procedure for Preparation of Compounds 4}

\subsubsection{Synthesis of Intermediates 7}

Aniline or 4-chloroaniline $(100 \mathrm{mmol})$, and diethyl malonate $(50 \mathrm{mmol})$ were properly mixed in a $250 \mathrm{~mL}$ beaker. The obtained mixture was irradiated in a microwave oven at the power of $320 \mathrm{~W}$ for 5 min. After irradiation, the crude product was recrystallised in ethanol to afford the desired product.

bis(4-Chlorophenyl)malonamide (7a): yield 95\%, white solid, ESIMS: $m / z: 323(\mathrm{M}+\mathrm{H})^{+}$

Diphenylmalonamide (7b): yield 91\%, white solid, ESIMS: $m / z: 255(\mathrm{M}+\mathrm{H})^{+}$ 


\subsubsection{Synthesis of Intermediates 8}

A mixture of 7a or $7 \mathbf{b}(2.0 \mathrm{mmol})$ with 5-6 times by weight polyphosphoric acid were stirred in an oil bath at $140-150{ }^{\circ} \mathrm{C}$ for $6 \mathrm{~h}$. Then the mixture was cooled, diluted with water and the resultant gum solidified by standing over night. The solid was filtered and dried in air. It was recrystallised from ethanol to afford corresponding hydroxyquinolones as creamy crystals.

6-Chloro-4-hydroxyquinolin-2(1H)-one (8a): white solid, yield: 82\%, ${ }^{1} \mathrm{H}-\mathrm{NMR}$ (300 MHz, DMSO- $\left.d_{6}, \delta \mathrm{ppm}\right): 5.80(\mathrm{~s}, 1 \mathrm{H}), 7.68(\mathrm{~s}, 1 \mathrm{H}), 7.27(\mathrm{dd}, 1 \mathrm{H}, J=8.6,4.8 \mathrm{~Hz}), 7.53(\mathrm{~d}, 1 \mathrm{H}, J=8.6 \mathrm{~Hz})$, 11.35 (brs, $1 \mathrm{H}, \mathrm{NH})$.

4-Hydroxyquinolin-2(1H)-one (8b): white solid, yield: 85\%, ${ }^{1} \mathrm{H}-\mathrm{NMR}$ (300 MHz, DMSO- $d_{6}$, $\delta \mathrm{ppm}): 5.83(\mathrm{~s}, 1 \mathrm{H}), 7.51-7.68(\mathrm{~m}, 3 \mathrm{H}), 7.23(\mathrm{~d}, 1 \mathrm{H}, J=8.0 \mathrm{~Hz}), 11.33$ (brs, $1 \mathrm{H}, \mathrm{NH})$.

\subsubsection{Synthesis of Intermediates 9}

A mixture of $8(84.47 \mathrm{mmol})$ in $\mathrm{POCl}_{3}(150 \mathrm{~mL})$ was heated under reflux for $3 \mathrm{~h}$. After cooling down, the mixture was slowly added to crushed ice while shaking. The precipitate was collected by filtration and washed several times with water. The product was dried under vacuum overnight to give the products as white solid which are pure enough for further use.

2,4,6-Trichloroquinoline (9a): white solid, yield 70\%, ${ }^{1} \mathrm{H}-\mathrm{NMR}\left(500 \mathrm{MHz}, \mathrm{CDCl}_{3}, \delta\right.$ ppm): 8.00 $(\mathrm{s}, 1 \mathrm{H}), 7.94(\mathrm{~d}, J=9.0 \mathrm{~Hz}, 1 \mathrm{H}), 7.66(\mathrm{~d}, J=9.0 \mathrm{~Hz}, 1 \mathrm{H}), 7.56(\mathrm{~s}, 1 \mathrm{H})$; ESIMS: $m / z: 232(\mathrm{M}+\mathrm{H})^{+}$.

2,4-Dichloroquinoline (9b): white solid, yield 66\%, ${ }^{1} \mathrm{H}-\mathrm{NMR}\left(500 \mathrm{MHz}, \mathrm{CDCl}_{3}, \delta \mathrm{ppm}\right): 8.16$ $(\mathrm{d}, J=8.0 \mathrm{~Hz}, 1 \mathrm{H}), 8.01(\mathrm{~d}, J=8.0 \mathrm{~Hz}, 1 \mathrm{H}), 7.80(\mathrm{t}, J=8.0 \mathrm{~Hz}, 1 \mathrm{H}), 7.65(\mathrm{t}, J=8.0 \mathrm{~Hz}, 1 \mathrm{H}), 7.47$ (s, 1H); ESIMS: $m / z: 198(\mathrm{M}+\mathrm{H})^{+}$.

\subsubsection{Synthesis of Intermediates $\mathbf{1 0}$}

To a solution of $9 \mathbf{a}$ or $9 \mathbf{b}(10.0 \mathrm{mmol})$ in DMF $(10 \mathrm{~mL})$ was added $\mathrm{Et}_{3} \mathrm{~N}(2.78 \mathrm{~mL}, 20 \mathrm{mmol})$ and a solution of thiol $(10 \mathrm{mmol})$ in DMF $(10 \mathrm{~mL})$ dropwise at $0{ }^{\circ} \mathrm{C}$. The reaction was warmed up after $10 \mathrm{~min}$ and stirred overnight at rt. $200 \mathrm{~mL}$ of EtOAc was added to the mixture and washed with water and brine successively. The organic layer was separated and dried over $\mathrm{Na}_{2} \mathrm{SO}_{4}$. The product was purified on a column after removal of the solvent under vacuum. In most of cases, less than $7 \%$ of dithio-substituted quinoline was formed.

2,6-Dichloro-4-(phenylthio)quinoline (10a): amorphous powder, yield: 69\%. ${ }^{1} \mathrm{H}-\mathrm{NMR}(300 \mathrm{MHz}$, $\left.\mathrm{CDCl}_{3}, \delta \mathrm{ppm}\right): 8.11(\mathrm{~s}, 1 \mathrm{H}), 7.88-7.50(\mathrm{~m}, 2 \mathrm{H}), 7.18-7.09(\mathrm{~m}, 5 \mathrm{H}), 6.72(\mathrm{~s}, 1 \mathrm{H})$; ESIMS: $m / z$ : $306(\mathrm{M}+\mathrm{H})^{+}$. 
2,6-Dichloro-4-(3,5-dimethylphenylthio)quinoline (10b): amorphous powder, yield: 69\%. ${ }^{1} \mathrm{H}-\mathrm{NMR}$ (300 MHz, $\left.\mathrm{CDCl}_{3}, \delta \mathrm{ppm}\right): 8.13(\mathrm{~s}, 1 \mathrm{H}), 7.88-7.50$ (m, 2H), 7.24 (s, 2H), $7.19(\mathrm{~s}, 1 \mathrm{H}), 6.62(\mathrm{~s}, 1 \mathrm{H})$, 2.34 (s, 6H); ESIMS: $m / z: 334(\mathrm{M}+\mathrm{H})^{+}$.

2-chloro-4-(3,5-dimethylphenylthio)quinoline (10c): amorphous powder, yield: $59 \%$. ${ }^{1} \mathrm{H}-\mathrm{NMR}$ (300 MHz, $\left.\mathrm{CDCl}_{3}, \delta \mathrm{ppm}\right): 8.23(\mathrm{~d}, J=8.0 \mathrm{~Hz}, 1 \mathrm{H}), 7.99-7.57(\mathrm{~m}, 3 \mathrm{H}), 7.23(\mathrm{~s}, 1 \mathrm{H}), 7.21(\mathrm{~s}, 1 \mathrm{H})$, $7.16(\mathrm{~s}, 1 \mathrm{H}), 6.63(\mathrm{~s}, \mathrm{IH}), 2.33(\mathrm{~s}, 6 \mathrm{H})$; ESIMS: $m / z: 282(\mathrm{M}+\mathrm{H})^{+}$.

\subsubsection{Synthesis of Target Compounds 4a}

A solution of compound $\mathbf{1 0}(0.50 \mathrm{mmol})$ in TFA $(2 \mathrm{~mL})$ and $\mathrm{HCl}(6 \mathrm{~N}, 2 \mathrm{~mL})$ was heated under microwave radiation at $120{ }^{\circ} \mathrm{C}$ for $20 \mathrm{~min}$. After cooling down, water $(20 \mathrm{~mL})$ was added. The precipitate was collected by filtration and washed with water several times. The product was air dried (71-85\%) and was pure enough without further purification. The solubility of the products in organic solvents is poor.

6-Chloro-4-(phenylthio)quinolin-2(1H)-one (4a1): amorphous powder, yield: 71\%. ${ }^{1} \mathrm{H}-\mathrm{NMR}(300 \mathrm{MHz}$, DMSO- $d_{6}, \delta$ ppm): $11.13(\mathrm{bs}, 1 \mathrm{H}), 7.81(\mathrm{~s}, 1 \mathrm{H}), 7.68-7.30(\mathrm{~m}, 2 \mathrm{H}), 7.08-6.89(\mathrm{~m}, 5 \mathrm{H}), 5.72(\mathrm{~s}, 1 \mathrm{H})$; ESIMS: $m / z$ : $288(\mathrm{M}+\mathrm{H})^{+}$; HRESIMS: calc for $\mathrm{C}_{15} \mathrm{H}_{11} \mathrm{CINOS}[\mathrm{M}+\mathrm{H}]^{+} 288.0250$, found 288.0261 .

6-Chloro-4-(3,5-dimethylphenylthio)quinolin-2(1H)-one (4a2): amorphous powder, yield: 77\%. ${ }^{1} \mathrm{H}-\mathrm{NMR}\left(300 \mathrm{MHz}, \mathrm{DMSO}-d_{6}, \delta \mathrm{ppm}\right): 11.38(\mathrm{bs}, 1 \mathrm{H}) 7.76(\mathrm{~s}, 1 \mathrm{H}), 7.68-7.30(\mathrm{~m}, 2 \mathrm{H}), 7.22(\mathrm{~s}, 2 \mathrm{H})$, $7.18(\mathrm{~s}, 1 \mathrm{H}), 5.82(\mathrm{~s}, 1 \mathrm{H}), 2.34(\mathrm{~s}, 6 \mathrm{H})$; ESIMS: $m / z$ : $316(\mathrm{M}+\mathrm{H})^{+}$; HRESIMS: calc for $\mathrm{C}_{17} \mathrm{H}_{15} \mathrm{CINOS}$ 316.0563 , found 316.0547 .

4-(3,5-dimethylphenylthio)quinolin-2(1H)-one (4a3): amorphous powder, yield: $85 \%$. ${ }^{1} \mathrm{H}-\mathrm{NMR}$ (300 MHz, DMSO- $d_{6}, \delta$ ppm): 11.66 (bs, $\left.1 \mathrm{H}\right), 7.88$ (d, $\left.J=8.0 \mathrm{~Hz}, \mathrm{IH}\right), 7.89-7.43$ (m, 3H), 7.251 $(\mathrm{s}, 2 \mathrm{H}), 7.13(\mathrm{~s}, 1 \mathrm{H}), 5.88(\mathrm{~s}, \mathrm{IH}), 2.32(\mathrm{~s}, 6 \mathrm{H})$; ESIMS: $m / z: 282(\mathrm{M}+\mathrm{H})^{+}$; HRESIMS: calc for $\mathrm{C}_{17} \mathrm{H}_{16} \mathrm{NOS}[\mathrm{M}+\mathrm{H}]^{+} 282.0953$, found 282.0950 .

\subsubsection{Synthesis of Target Compounds $\mathbf{4 b}$}

To a solution of compound $4 \mathrm{a}(0.25 \mathrm{mmol})$ in a mixture of $\mathrm{CH}_{2} \mathrm{Cl}_{2}$ and $\mathrm{MeOH}(50 \mathrm{~mL})$ was added 1.1 equiv. of 3 -chlorobenzoperoxoic acid. After stirring overnight, water $(50 \mathrm{~mL})$ was added. The mixture was extracted with $\mathrm{CH}_{2} \mathrm{Cl}_{2}$ and evaporated to give a residue which were further purified on silica gel column to give compounds $4 \mathbf{b}(66-75 \%)$.

6-Chloro-4-(phenylsulfinyl)quinolin-2(1H)-one (4b1): amorphous powder, yield: $66 \%$. ${ }^{1} \mathrm{H}-\mathrm{NMR}$ (300 MHz, DMSO- $d_{6}, \delta$ ppm): 11.85 (bs, 1H), 7.91 (s, 1H), 7.88-7.47 (m, 7H), $5.92(\mathrm{~s}, 1 \mathrm{H}), 2.39$ (s, 6H); ESIMS: $m / z$ : $304(\mathrm{M}+\mathrm{H})^{+}$; HRESIMS: calc for $\mathrm{C}_{15} \mathrm{H}_{11} \mathrm{ClNO}_{2} \mathrm{~S}[\mathrm{M}+\mathrm{H}]^{+}$304.0199, found 304.0208.

6-Chloro-4-(3,5-dimethylphenylsulfinyl)quinolin-2(1H)-one (4b2): amorphous powder, yield: 75\%. ${ }^{1} \mathrm{H}-\mathrm{NMR}\left(300 \mathrm{MHz}, \mathrm{DMSO}-d_{6}, \delta \mathrm{ppm}\right): 11.40$ (bs, $\left.1 \mathrm{H}\right), 7.96$ (s, 1H), 7.88-7.55 (m, 2H), 7. 47 (s, 1H), 
7. $42(\mathrm{~s}, 1 \mathrm{H}), 7.40(\mathrm{~s}, 1 \mathrm{H}), 6.01(\mathrm{~s}, 1 \mathrm{H}), 2.32(\mathrm{~s}, 6 \mathrm{H})$; ESIMS: $m / z: 332(\mathrm{M}+\mathrm{H})^{+}$; HRESIMS: calc for $\mathrm{C}_{17} \mathrm{H}_{15} \mathrm{ClNO}_{2} \mathrm{~S}[\mathrm{M}+\mathrm{H}]^{+}$332.0512, found 332.0509.

\subsubsection{Synthesis of Target Compounds 4c}

To a solution of compound $\mathbf{4 b}(0.2 \mathrm{mmol})$ in a mixture of $\mathrm{CH}_{2} \mathrm{Cl}_{2}$ and $\mathrm{MeOH}(50 \mathrm{~mL})$ was added 1.1 equiv. 3-chlorobenzoperoxoic acid. After stirring overnight, $50 \mathrm{~mL}$ of water was added. The mixture was extracted with $\mathrm{CH}_{2} \mathrm{Cl}_{2}$ and evaporated to give a residue which were further purified on silica gel column to give compound $4 \mathbf{b}(60-66 \%)$.

6-Chloro-4-(phenylsulfonyl)quinolin-2(1H)-one (4c1): amorphous powder, yield: 64\%. ${ }^{1} \mathrm{H}-\mathrm{NMR}$ (300 $\left.\mathrm{MHz}, \mathrm{CDCl}_{3}\right): 11.51$ (bs, IH), $8.10(\mathrm{~s}, 1 \mathrm{H}), 7.91-7.49(\mathrm{~m}, 5 \mathrm{H}), 7.39(\mathrm{~d}, J=8.0 \mathrm{~Hz}, 1 \mathrm{H}), 7.29$ $(\mathrm{d}, J=8.0 \mathrm{~Hz}, 1 \mathrm{H}), 6.12(\mathrm{~s}, 1 \mathrm{H})$; ESIMS: $\mathrm{m} / \mathrm{z}: 320(\mathrm{M}+\mathrm{H})^{+}$; HRESIMS: calc for $\mathrm{C}_{15} \mathrm{H}_{11} \mathrm{CINO}_{3} \mathrm{~S}$ $[\mathrm{M}+\mathrm{H}]^{+} 330.0148$, found 320.0154 .

6-Chloro-4-(3,5-dimethylphenylsulfonyl)quinolin-2(1H)-one (4c2): amorphous powder, yield: 60\%. ${ }^{1} \mathrm{H}-\mathrm{NMR}\left(300 \mathrm{MHz}, \mathrm{CDCl}_{3}, \delta \mathrm{ppm}\right): 11.86$ (bs, IH), $8.00(\mathrm{~s}, 1 \mathrm{H}), 7.98-7.69(\mathrm{~m}, 2 \mathrm{H}), 7.57$ (s, 2H), $7.39(\mathrm{~s}, 1 \mathrm{H}), 5.95(\mathrm{~s}, 1 \mathrm{H}), 2.35(\mathrm{~s}, 6 \mathrm{H})$; ESIMS: $m / z$ : $348(\mathrm{M}+\mathrm{H})^{+}$; HRESIMS: calc for $\mathrm{C}_{17} \mathrm{H}_{15} \mathrm{ClNO}_{3} \mathrm{~S}$ $[\mathrm{M}+\mathrm{H}]^{+} 348.0461$, found 348.0470 .

\subsubsection{Synthesis of Target Compounds $\mathbf{4 d}$}

To a solution of 9a $(10.0 \mathrm{mmol})$ in DMF $(10 \mathrm{~mL})$ was added $\mathrm{Et}_{3} \mathrm{~N}(2.78 \mathrm{~mL}, 20 \mathrm{mmol})$ and a solution of phenol $(10 \mathrm{mmol})$ in DMF $(10 \mathrm{~mL})$ dropwise at $0{ }^{\circ} \mathrm{C}$. The reaction was warmed up after 10 min and stirred for $24 \mathrm{~h}$ at rt. $200 \mathrm{~mL}$ of EtOAc was added to the mixture and washed with water and brine successively. The organic layer was separated and dried over $\mathrm{Na}_{2} \mathrm{SO}_{4}$. The product 11 was purified on column after removal of solvent under vacuum with yield of $75-86 \%$. A solution of compound $11(0.50 \mathrm{mmol})$ in TFA $(2 \mathrm{~mL})$ and $\mathrm{HCl}(6 \mathrm{~N}, 2 \mathrm{~mL})$ was then heated under microwave radiation at $120{ }^{\circ} \mathrm{C}$ for $20 \mathrm{~min}$. After cooling down, $20 \mathrm{~mL}$ of water was added. The precipitate was collected by filtration and washed with water for several times. The product was air dried (71-85\%) and was pure enough without further purification.

6-Chloro-4-phenoxyquinolin-2(1H)-one (4d1): amorphous powder, yield: 71\%. ${ }^{1} \mathrm{H}-\mathrm{NMR}(300 \mathrm{MHz}$, DMSO- $\left.d_{6}, \delta \mathrm{ppm}\right): 11.94(\mathrm{bs}, 1 \mathrm{H}), 7.71(\mathrm{~s}, 1 \mathrm{H}), 7.60-7.10(\mathrm{~m}, 2 \mathrm{H}), 7.01-6.67(\mathrm{~m}, 5 \mathrm{H}), 5.70(\mathrm{~s}, 1 \mathrm{H})$; ESIMS: $m / z$ : $272(\mathrm{M}+\mathrm{H})^{+}$; HRESIMS: calc for $\mathrm{C}_{15} \mathrm{H}_{11} \mathrm{ClNO}_{2}[\mathrm{M}+\mathrm{H}]^{+} 272.0478$, found 272.0470 .

6-Chloro-4-(3,5-dimethylphenoxy)quinolin-2(1H)-one (4d2): amorphous powder, yield: 77\%. ${ }^{1} \mathrm{H}-\mathrm{NMR}$ (300 MHz, DMSO- $d_{6}, \delta$ ppm ): 11.64 (bs, 1H)7.70 (s, 1H), 7.65-7.31 (m, 2H), 6.89 (s, 2H), 6.93 $(\mathrm{s}, 1 \mathrm{H}), 5.72(\mathrm{~s}, 1 \mathrm{H}), 2.33(\mathrm{~s}, 6 \mathrm{H})$; ESIMS: $m / z: 300(\mathrm{M}+\mathrm{H})^{+}$; HRESIMS: calc for $\mathrm{C}_{17} \mathrm{H}_{15} \mathrm{CINO}_{2}$ $[\mathrm{M}+\mathrm{H}]^{+} 300.0791$, found 300.0775 . 


\subsubsection{General Procedure for Preparation of Compounds 5}

\subsubsection{Synthesis of Intermediate $\mathbf{1 2}$}

4-Chloroaniline $(19.2 \mathrm{~g}, 0.1 \mathrm{~mol})$, DIEA $(0.12 \mathrm{~mol})$ and toluene $(40 \mathrm{~mL})$ were placed in a $100 \mathrm{~mL}$ flask and stirred at $\mathrm{rt}$, then $\mathrm{Boc}_{2} \mathrm{O}(26 \mathrm{~g}, 0.12 \mathrm{~mol})$ was added, and the solution was stirred at rt until the completion of the reaction monitored by TCL. Then the solution was poured into water and extracted with DCM and then the organic layer was washed by water and dried over anhydrous $\mathrm{Na}_{2} \mathrm{SO}_{4}$. Then the organic solvent was removed under vacuum to give crude product which was further purified on Si gel column chromatography and eluted with petroleum ether (PET)-EtOAc (6:1) to give the compound tert-butyl 4-chlorophenylcarbamate (12) $21.3 \mathrm{~g}$, white solid, yield 94\%. ${ }^{1} \mathrm{H}-\mathrm{NMR}$ $\left(\mathrm{CDCl}_{3}, \delta \mathrm{ppm}\right): 7.31-7.22(\mathrm{~m}, 4 \mathrm{H}), 6.54$ (brs, $\left.1 \mathrm{H}, \mathrm{NH}\right), 1.51\left(\mathrm{~s}, 9 \mathrm{H}, \mathrm{CH}_{3}\right)$; positive FABMS $m / z(\%)$ : $227[\mathrm{M}]^{+}(60), 172(83), 57(100)$.

\subsubsection{Synthesis of Compound $\mathbf{1 3}$}

Compound 12 was taken as an example. To a $100 \mathrm{~mL}$ flask, $\mathrm{Boc}_{2} \mathrm{O}$ (11.4 g, $\left.50 \mathrm{mmol}\right)$ and anhydrous THF $(30 \mathrm{~mL})$ were added under an atmosphere of $\mathrm{N}_{2}$. The solution was stirred and cooled to $-78^{\circ} \mathrm{C}$, then $\mathrm{t}$-BuLi solution in THF $(110 \mathrm{mmol})$ was added dropwise under $\mathrm{N}_{2}$. The solution was kept at $-78{ }^{\circ} \mathrm{C}$ under stirring for $1 \mathrm{~h}$ and then warmed up to $-40^{\circ} \mathrm{C}$. Methyl benzoate $(60 \mathrm{mmol}$, in $10 \mathrm{~mL}$ THF) was added dropwise under $\mathrm{N}_{2}$ in $15 \mathrm{~min}$. The solution was kept in $-40{ }^{\circ} \mathrm{C}$ for another $1 \mathrm{~h}$ and warmed up to rt. The solution was poured into ice cooled $\mathrm{NH}_{4} \mathrm{Cl}$ solution and extracted with EtOAc. The combined organic layer was washed with brine and dried over anhydrous $\mathrm{Na}_{2} \mathrm{SO}_{4}$ and then evaporated to give crude $N$-Boc protected 13. Without further purification, the crude product was dissolved in $30 \mathrm{~mL} \mathrm{EtOH}$, and then $3 \mathrm{~mol} / \mathrm{L} \mathrm{HCl}$ solution $(10 \mathrm{~mL})$ was added. The mixture was refluxed until the completion of the reaction. Then the solution was adjusted to $\mathrm{pH} 8$ using saturated $\mathrm{NaHCO}_{3}$ solution and extracted with DCM successively. The organic layer was washed with brine and dried over anhydrous $\mathrm{Na}_{2} \mathrm{SO}_{4}$ and then evaporated to give a residue which was further purified on Si CC to give compound 13 (3.46 g, yield: 30\%).

(2-Amino-5-chlorophenyl)(phenyl)methanone (13a): ${ }^{1} \mathrm{H}-\mathrm{NMR} \quad$ (DMSO- $d_{6}, \quad \delta$ ppm): 7.64-7.33 (m, 7H), $6.99(\mathrm{~d}, J=8.8 \mathrm{~Hz}, 1 \mathrm{H}), 6.08$ (brs, $\left.2 \mathrm{H}, \mathrm{NH}_{2}\right)$; positive FABMS $m / z(\%): 232[\mathrm{M}+1]^{+}(100)$.

(2-Amino-5-chlorophenyl)(2-fluorophenyl)methanone (13b): yellow amorphous powder, yield 27\%, ${ }^{1} \mathrm{H}-\mathrm{NMR}$ (DMSO- $\left.d_{6}, \delta \mathrm{ppm}\right): 7.50-6.15(\mathrm{~m}, 6 \mathrm{H}), 6.67(\mathrm{~d}, J=8.8 \mathrm{~Hz}, 1 \mathrm{H}), 6.38$ (brs, $2 \mathrm{H}, \mathrm{NH}_{2}$ ); positive FABMS $m / z(\%): 250[\mathrm{M}+1]^{+}(100) .249[\mathrm{M}]^{+}(100)$.

(2-Amino-5-chlorophenyl)(2-chlorophenyl)methanone (13c): yellow amorphous powder, yield 31\%, ${ }^{1} \mathrm{H}-\mathrm{NMR}$ (DMSO- $\left.d_{6}, \delta \mathrm{ppm}\right): 7.46-7.11(\mathrm{~m}, 6 \mathrm{H}), 6.68-6.65(\mathrm{~m}, 1 \mathrm{H}), 6.47$ (brs, $2 \mathrm{H}, \mathrm{NH}_{2}$ ); positive FABMS $m / z(\%): 266[\mathrm{M}+1]^{+}(100)$. 


\subsubsection{Synthesis of Compounds 5}

Compound 5a was taken as an example. A $30 \mathrm{~mL}$, 2-necked flask was charged with compound 13a $(1 \mathrm{mmol}, 231 \mathrm{mg})$ and THF $(5 \mathrm{~mL})$. The resulting solution was cooled to $0{ }^{\circ} \mathrm{C}$ and LiHMDS $(6 \mathrm{~mL}$, $1 \mathrm{M}$ in THF) was added over $5 \mathrm{~min}$. The internal temperature was controlled $<5{ }^{\circ} \mathrm{C}$ for $10 \mathrm{~min}$, then EtOAc (144 mg, $2 \mathrm{mmol}$ ) was added over $1 \mathrm{~min}$. The reaction solution was allowed to warm up to $\mathrm{rt}$ and stirred at $\mathrm{rt}$ for $2 \mathrm{~h}$. Then water $(5 \mathrm{~mL})$ was added, and the reaction mixture was stirred at $\mathrm{rt}$ for another $24 \mathrm{~h}$. The solution was poured into $50 \mathrm{~mL}$ ice cooled water, and a water suspension formed. The suspension was filtered and the solid was further purified on $\mathrm{Si} \mathrm{CC}$ eluted with $\mathrm{CHCl}_{3} / \mathrm{CH}_{3} \mathrm{OH}$ (97:3) to give white amorphous powder 5a (212 mg, yield: 83\%).

6-Chloro-4-phenylquinolin-2(1H)-one (5a): white amorphous powder, yield:70\% ${ }^{1} \mathrm{H}-\mathrm{NMR}$ (DMSO- $d_{6}$, $\delta \mathrm{ppm}): 12.02(\mathrm{~s}, 1 \mathrm{H}, \mathrm{NH}), 7.60-7.39(\mathrm{~m}, 7 \mathrm{H}), 7.26(\mathrm{~s}, 1 \mathrm{H}), 6.45(\mathrm{~s}, 1 \mathrm{H})$; positive FABMS m/z $(\%)$ : $256[\mathrm{M}+1]^{+}(50), 73$ (100). HRESIMS: calc for $\mathrm{C}_{15} \mathrm{H}_{11} \mathrm{ClNO}[\mathrm{M}+\mathrm{H}]^{+} 256.0529$, found 256.0548.

6-Chloro-4-(2-fluorophenyl)quinolin-2(1H)-one (5b): white amorphous powder, yield: $77 \%,{ }^{1} \mathrm{H}-\mathrm{NMR}$ $\left(\mathrm{CDCl}_{3}-\mathrm{CD}_{3} \mathrm{OD}, \delta \mathrm{ppm}\right): 8.16-8.10(\mathrm{~m}, 3 \mathrm{H}), 8.01-7.96(\mathrm{~m}, 3 \mathrm{H}), 7.89-7.87(\mathrm{~m}, 2 \mathrm{H})$; EI-MS m/z (\%): $275[\mathrm{M}+2]^{+}(6), 274[\mathrm{M}+1]^{+}(4), 273[\mathrm{M}]^{+}$(18), 246 (17), 210 (65), 131 (100), 117 (50), 105 (21), 91 (84): HRESIMS: calc for $\mathrm{C}_{15} \mathrm{H}_{10} \mathrm{ClFNO}[\mathrm{M}+\mathrm{H}]^{+} 274.0435$, found 274.0448 .

6-Chloro-4-(2-chlorophenyl)quinolin-2(1H)-one (5c): white amorphous powder, yield: $80 \%,{ }^{1} \mathrm{H}-\mathrm{NMR}$ (DMSO- $\left.d_{6}, \delta \mathrm{ppm}\right): 12.11(\mathrm{~s}, 1 \mathrm{H}, \mathrm{NH}), 7.67-7.40(\mathrm{~m}, 4 \mathrm{H}), 6.84(\mathrm{~d}, J=2.2 \mathrm{~Hz}, 1 \mathrm{H}), 6.47(\mathrm{~s}, 1 \mathrm{H})$; EI-MS m/z (\%): $293[\mathrm{M}+4]^{+}$(4), $293[\mathrm{M}+3]^{+}$(3), $291[\mathrm{M}+2]^{+}$(10), $289[\mathrm{M}]^{+}$(20), 167 (30), 149 (100); HRESIMS: calc for $\mathrm{C}_{15} \mathrm{H}_{10} \mathrm{C}_{12} \mathrm{NO}[\mathrm{M}+\mathrm{H}]^{+} 290.0139$, found 290.0151 .

\subsection{General Procedure for HIV-1 RT Inhibitory Assay}

HIV-1 reverse transcriptase (RT) activity was measured using a commercially available ELISA RT kit (Roche) according to the instructions of the manufacturer. The compounds were incubated with DIG-labeled reaction mixture at $37{ }^{\circ} \mathrm{C}$ for $2 \mathrm{~h}$, then anti-DIG-POD solution was added, followed by substrate ABTS. Efaviren was used as a positive control. The absorbency at $405 \mathrm{~nm} / 490 \mathrm{~nm}$ (A405/490) was read on Bio-Tek ELx 800 ELISA reader.

\subsection{General Procedures for Docking Study}

CDOCK was used for the docking study. The CHARMM force field was used for the energy minimizations in the docking process. The X-ray crystal structure of reverse transcriptase complexed with efavirenz was retrieved from PDB (PDB code: 1FK9). The active site was defined as all residues within $6.5 \AA$ radius of the cocrystallized efavirenz. Starting from the ligand configuration, a set of 10 different orientations was randomly generated and ranked according to their binding free energy. The docking mode was chosen on the basis of binding affinity rank. 


\section{Conclusions}

In summary, a group of quinoneline-2-one analogues with activity against HIV-1 RT were synthesized based on the SAR established by Freeman and known crystal structures. The SAR and docking studies of the titled compounds were analyzed. Analogues $\mathbf{4 a 2}$ and $\mathbf{4 d} \mathbf{2}$ demonstrated the most activity among these analogues with a similar mode of interaction with RT residues of the allosteric pocket as known NNRTIs. Further structure modifications and cell-based in vitro anti-HIV-1 assay studies of these quinolin-2-one derivatives will be reported in due course.

\section{Acknowledgments}

The authors are grateful to Qiong Gu's research group for the docking study performed at the School of Pharmaceutical Sciences, Sun Yat-sen University. This work was partly supported by the Talent Introduction Project in Hunan Agricultural University (11YJ04).

\section{References}

1. Mehellou, Y.; Clercq, E.D. Twenty-six years of anti-HIV drug discovery: Where do we stand and where do we go? J. Med. Chem. 2010, 53, 521-538.

2. Ragno, R.; Coluccia, A.; Regina, G.L.; Martino, G.D.; Piscitelli, F.; Lavecchia, A.; Novellino, E.; Bergamini, A.; Ciaprini, C.; Sinistro, A.; et al. Design, molecular modeling, synthesis, and anti-HIV-1 activity of new indolyl aryl sulfones. Novel derivatives of the indole-2-carboxamide. J. Med. Chem. 2006, 49, 3172-3184.

3. Barreca, M.L.; Rao, A.; Luca, L.D.; Iraci, N.; Monforte, A.; Maga, G.; Clercq, E.D.; Pannecouque, C.; Balzarini, J.; Chimirri, A. Discovery of novel benzimidazolones as potent non-nucleoside reverse transcriptase inhibitors active against wild-type and mutant HIV-1 strains. Bioorg. Med. Chem. Lett. 2007, 17, 1956-1960.

4. Regina, G.L.; Coluccia, A.; Piscitelli, F.; Bergamini, A.; Sinistro, A.; Cavazza, A.; Maga, G.; Samuele, A.; Zanoli, S.; Novellino, E.; et al. Indolyl aryl sulfones as HIV-1 non-nucleoside reverse transcriptase inhibitors: Role of two halogen atoms at the indole ring in developing new analogues with improved antiviral activity. J. Med. Chem. 2007, 50, 5034-5038.

5. Jones, L.H.; Allan, G.; Barba, O.; Burt, C.; Corbau, R.; Dupont, T.; Knochel, T.; Irving, S.; Middleton, D. S.; Mowbray, C. E.; et al. Novel indazole non-nucleoside reverse transcriptase inhibitors using molecular hybridization based on crystallographic overlays. J. Med. Chem. 2009, 52, 1219-1923.

6. Freeman, G.A.; Andrews, C.W., III.; Hopkins, A.L.; Lowell, G.S.; Schaller, L.T.; Cowan, J.R.; Gonzales, S.S.; Koszalka, G.W.; Hazen, R.J.; Boone, L.R.; et al. Design of non-nucleoside inhibitors of HIV-1 reverse transcriptase with improved drug resistance properties. 2. J. Med. Chem. 2004, 47, 5923-5936.

7. Barreca, M.L.; Rao, A.; Luca, L.D.; Zappalà, M.; Monforte, A.; Maga, G.; Pannecouque, C.; Balzarini, J.; Clercq, E.D.; Chimirri, A.; Monforte, P. Computational strategies in discovering novel non-nucleoside inhibitors of HIV-1 RT. J. Med. Chem. 2005, 48, 3433-3437. 
8. Monforte, A.; Logoteta, P.; Ferro, S.; Luca, L.D.; Iraci, N.; Maga, G.; Clercq, E.D.; Pannecouque, C.; Chimirri, A. Design, synthesis, and structure-activity relationships of 1,3dihydrobenzimidazol-2-one analogues as anti-HIV agents. Bioorg. Med. Chem. Lett. 2009, 17, 5962-5967.

9. Mccormick, J.L.; McKee, T.C.; Cardellina, J.H., II.; Boyd, M.R. HIV inhibitory natural products. 26. quinoline alkaloids from Euodia roxburghiana. J. Nat. Prod. 1996, 59, 469-471.

10. Guillemont, J.; benjahad, A.; Oumouch, S.; Decrane, L.; Palandjian, P.; Vernier, D.; Queguiner, L.; Andries, K.; Béthune, M.; Hertogs, K.; et al. Synthesis and biological evaluation of C-5 methyl substituted 4-arylthio and 4-aryloxy-3-Iodopyridin-2(1H)-one type anti-HIV agents. J. Med. Chem. 2009, 52, 7473-7487.

11. Mowbray, C.E.; Burt, C.; Corbau, R.; Perros, M.; Tran, I.; Stupple, P.A.; Webster, R.; Wood, A. Pyrazole NNRTIs 1: Design and initial optimisation of a novel template. Bioorg. Med. Chem. Lett. 2009, 19, 5599-5602.

12. Xu. B.; Sun. Y.; Guo, Y.; Cao, Y.; Yu, T. Synthesis and biological evaluation of N4(hetero)arylsulfonylquinoxalinones as HIV-1 reverse transcriptase inhibitors. Bioorg. Med. Chem. 2009, 17, 2767-2774.

13. Ren, J.; Chamberlain, P.P.; Stamp, A.; Short, S.A.; Weaver, K.L.; Romines, K.R.; Hazen, R.; Freeman, A.; Ferris, R.G.; Andrew, C.W.; et al. Structural basis for the improved drug resistance profile of new generation benzophenone non-nucleoside HIV-1 reverse transcriptase inhibitors. J. Med. Chem. 2008, 51, 5000-5008.

14. O'llah, E.; Rufchahi, M. Synthesis of 6-chloro and 6-fluoro-4-hydroxyl-2-quinolone and their azo disperse dyes. Chin. Chem. Lett. 2010, 21, 542-546.

15. Zhu, Q.; Reza, F.; Yang, Z.; Anthony, A.; Liu, Y.; Joon, C.H.; Richard, W. 4-Thio substituted quinoline and naphthyridine compounds. Patent EP 2,061,466, 2009.

16. Whisler, M.C.; MacNeil, S.; Snieckus, V.; Beak, P. Beyond thermodynamic acidity: A perspective on the complex-induced proximity effect (CIPE) in deprotonation reactions. Angew. Chem. Int. Ed. Engl. 2004, 43, 2206-2225.

17. Hewawasam, P.; Fan, W.; Knipe, J.; Moon, S.L.; Boissard, C.G.; Gribkoff, V.K.; Starrett, J.E. The synthesis and structure-activity relationships of 4-aryl-3-aminoquinolin-2-ones: A new class of calcium-dependent, large conductance, potassium (maxi-K) channel openers targeted for post-stroke neuroprotection. Bioorg. Med. Chem. Lett. 2002, 12, 1779-1783.

18. Ren, J.; Milton, J.; Weaver, K.L.; Short, S.A.; Stuart, D.I. Structural basis for the resilience of efavirenz (DMP-266) to drug resistance mutations in HIV-1 reverse transcriptase. Structure 2000, 8, 1089-1094.

Sample Availability: Samples of the all compounds are available from the authors.

(C) 2011 by the authors; licensee MDPI, Basel, Switzerland. This article is an open access article distributed under the terms and conditions of the Creative Commons Attribution license (http://creativecommons.org/licenses/by/3.0/). 